\title{
Perkembangan Pembuatan Tenun Melayu Siak : Suatu Tinjauan Historis
}

\author{
Bunari, Asyrul Fikri, Piki Setri Pernantah, Yanuar Al-Fiqri \\ bunari@lecturer.unri.ac.id \\ Universitas Riau
}

\begin{abstract}
The Siak weaving is a Riau Malay cultural heritage that has motifs with certain philosophical meanings. In addition, in the manufacturing process, there have been many developments, both in terms of materials and tools used. The study in this paper aims to describe the development of The Siak weaving techniques based on the categories of materials and tools used from time to time. The development of The Siak Weaving tools aims to increase production yields and shorten processing time. The method used in this study is the historical method with the stages of heuristics, verification, interpretation and historiography. From the results of the study, it can be concluded that changes in weaving production equipment affect the impact of, among others, the number of workers, budget efficiency, quality, and quantity of production.
\end{abstract}

Keywords: Development, Engineering, Manufacture, Weaving, Siak

\begin{abstract}
Abstrak
Tenun Siak merupakan warisan budaya Melayu Riau yang memiliki motif dengan makna filosofis tertentu. Selain itu, dalam proses pembuatannya banyak mengalami perkembangan baik dari bahan maupun alat yang digunakan. Kajian pada tulisan ini bertujuan untuk mendeskripsikan perkembangan teknik pembuatan tenun Siak berdasarkan kategori bahan dan alat yang digunakan dari masa ke masa. Perkembangan alat pembuatan Tenun Siak bertujuan untuk meningkatkan hasil produksi dan mempersingkat waktu pengerjaan. Metode yang digunakan dalam kajian ini yaitu metode sejarah dengan tahapan heuristik, verifikasi, interpretasi dan historiografi. Dari hasil kajian dapat disimpulkan bahwa perubahan pada alat produksi tenun mempengaruhi dampak antara lain jumlah tenaga kerja, efisensi anggaran, kualitas dan kuantitas produksi.
\end{abstract}

Kata Kunci: Perkembangan, Teknik, Pembuatan, Tenun, Siak 


\section{Pendahuluan}

Budaya menurut Sirajuddin (2014) berasal dari bahasa Sansekerta yaitu buddhayah, berasal dari bentuk jamak buddhi (budi atau akal), yang berarti berkaitan dengan akal dan budi manusia. Budaya adalah gaya hidup yang dinamis dan dimiliki bersama oleh suatu komunitas masyarakat yang diwariskan dari generasi ke generasi yang di dalamnya terdiri atas unsur-unsur yang komplek, termasuk sistem agama, politik, adat istiadat, bahasa, perkakas, pakaian, bangunan dan karya seni. Definisi lain tentang budaya menurut Joko (2009) adalah penempatan istilah kebudayaan dan budaya. Kebudayaan adalah suatu perkembangan dari kata majemuk budidaya, yang berarti daya dan budi. Oleh karena itu, budaya merupakan daya dari budi yang berupa cipta, karsa dan rasa, sedangkan kebudayaan adalah hasil dari cipta, karsa dan karya tersebut. Manusia dan kebudayaan tak terpisahkan, secara bersama-sama menyusun kehidupan (Kistanto, 2017). Ditambahkan Abdulsyani (2007), menjelaskan bahwa kebudayaan (culture) adalah suatu komponen penting dalam kehidupan masyarakat, khususnya didalam struktur sosial. Secara sederhana kebudayaan dapat dikatakan sebagai suatu cara hidup atau dalam istilah bahasa Inggris way of life. Cara hidup atau pandangan hidup hal ini meliputi cara berpikir, cara berencana dan cara bertindak, disamping segala hasil karya nyata yang dianggap berguna, benar dan dipatuhi oleh anggota-anggota masyarakat atas kesepakatan secara bersama- sama. Menurut Dali (2016), kebudayaan diwariskan kepada generasi berikutnya dalam bentuk seperti nyayian, pantun, puisi, perkakas, ritual dalam upacara adat dan lain sebagainya, dimana kebudayaan suatu masyarakat juga mengandung unsur kebaikan pada sisi kehidupan manusia.

Proses pewarisan budaya tersebut juga dapat dilihat pada eksistensi kain tradisional di setiap daerah di Indonesia yang menurut kajian BPS dan ISEAS (Institute of South Asian Studies) terdapat sekitar 633 suku (Pitoyo, A.J., \& Triwahyudi, 2017). Beberapa diantaranya tersebar mulai dari kain upe ulen-ulen dari Aceh, Ulos dari Sumatera Utara, Kain Tenun Melayu dari Riau, Kain Tapisnya dari Lampung, Kain batik dari Jawa, Kain Sasirangan dari Kalimantan Selatan, Kain Songket dari Minangkabau, dan sebagainya. Menurut Kartiwa (1981), keanekaragaman kain - kain tradisional dihasilkan oleh perbedaan geografis, flora, fauna, perbedaan gaya hidup dan mata pencaharian. Kain menurut Suadnyana (2020) bukan hanya hasil kerajinan turun- temurun bagi masyarakat, melainkan juga bentuk identitas kultural dan artefak ritual yang terus berkembang sebagai komoditas berbasis budaya. Alajaji (2019) menyimpulkan bahwa kain yang digunakan pada suku tertentu menggambarkan gaya hidup dan karakter yang memiliki nilai dan makna tertentu. Kain tradisional tersebut tidak hanya memiliki motif yang beraneka ragam, tetapi juga teknik pengolahan kain tradisional di Indonesia juga beranekaragam. Dengan teknik pengolahan berbeda akan menghasilkan motif yang beragam, ada dengan cara ditenun, celup, lukis dan dicap (Wahyudi, J., \& dan Maulida, 2019).

Riau memiliki salah satu hasil kebudayaan yang unik dan layak diunggulkan, yakni tenun Melayu Siak. Pada masyarakat Melayu Riau tenun songket tradisional 
selalu dihiasi dengan berbagai motif-motif hias tertentu dan setiap motif mempunyai makna terhadap sipemakainya(Guslinda \& Kurniaman, 2016). Tenunan Melayu Siak telah ada sejak Siak masih berupa kesultanan dengan dipimpin oleh tengku Syaid Ali, bergelar Sultan Assaidis Syarif Ali Bin Abdu Jalil Baalawi tahun 1784-1810 (Maulia, 2015). Berbicara soal Tenun Siak, tidak luput dari pembahasan bahwa wilayah Siak yang memiliki sejarah panjang, mulai dari menjadi bahagian dari kerajaan Johor, lalu menjadi sebuah kerajaan yang berdiri sendiri hingga berhasil melepaskan diri dari dominasi berbagai kekuatan politik di sekitarnya, menjadi sebuah kabupaten yang menerapkan sistem demokrasi modern dalam penyelenggaraan pemerintahannya (Roza, 2012). Melayu Riau (terutama Siak) dengan segala diskursusnya merupakan suatu identitas budaya yang dapat dikaji secara keilmuan dan menjadi identitas bagi pemiliki kebudayaannya. Menurut (Ibrahim, B., Fikri, A., \& Pernantah, 2019), dijelaskan bahwa dalam sosial kehidupan masyarakat Melayu Riau, pakaian tidak hanya berfungsi untuk melindungi tubuh dari panas dan dingin tetapi semua pakaian selalu dikaitkan dengan pergaulan norma, agama, dan adat istiadat. Dalam konteks ini budaya melayu atau kemelayuan memang harus dilihat secara dinamis, mengingat beragamnya definisi terkait identitas Melayu dewasa ini (Prayogi, 2016).

Dalam sejarahnya, proses pembuatan kain Tenun Siak pernah mengalami beberapa perubahan dari masa ke masa dari segi alat dan bahan. Perubahan ini disebabkan oleh beberapa factor, antara lain; bahan baku yang semakin mahal, alat yang kurang efisien, bahkan situasi dan kondisi politik kolonial ikut mempengaruhi proses pembuatan Kain Tenun Siak. Sebagai salah satu kerajaan yang terbesar berada di pulau Sumatera, tentu persoalan pakaian dan tenunan yang ada di Siak adalah satu hal yang sangat penting. Sebab, berkaitan dengan marwah dan penampilan para raja dan keluarga kerajaan Siak. Tenun Siak tidak hanya sekedar dijadikan pakaian tetapi tentunya memiliki nilai luhur yang tinggi yang relevan dengan budaya Melayu Siak (Ibrahim, B., Fikri, A., \& Pernantah, 2019). Oleh sebab itu, tenun Siak tentu memiliki posisi penting di dalam kehidupan sosial dan budaya kerajaan. Pada masanya, Siak bisa dikatakan sebagai sentra tenun khusus untuk pakaian para bangsawan di kerajaan (Lestari, S. \& Riyanti, 2017). Hal itu disebabkan karena seni kerajinan tenun sangat berkembang pesat di Siak. Kajian pada tulisan ini berfokus pada perkembangan bahan dan alat dalam pembuatan Kain Tenun Siak dari masa penjajahan hingga masa kemerdekaan sehingga relevan dengan eksistensi Kerajaan Siak.

\section{Metode Penelitian}

Metode yang digunakan dalam penulisan artikel ini adalah metode sejarah dengan tahapan yaitu heuristik (pengumpulan data), verifikasi (kritik sumber), interpretasi (penafsiran data), dan historiografi (penulisan sejarah). Metode sejarah tersebut dikombinasikan dengan beberapa pendekatan yaitu paradigma sejarah etnik (ethnohistory). Fokusnya adalah pada proses perkembangan budaya dan sejarah masyarakat (Strong, 2015). Pengumpulan data meliputi beberapa cara yaitu wawancara, studi lapangan, dokumentasi hingga studi literature berbagai sumber 
(buku dan jurnal ilmiah). Sumber-sumber yang telah dikumpulkan tersebut dilakukan kritik atau verifikasi dengan teknik elaborasi menggunakan pendekatan sejarah etnik. Elaborasi dilakukan untuk memberikan perspektif yang tajam, analitis, dan diakronis tentang budaya dan peninggalannya sehingga menghasilkan temuan atau kesimpulan baru. Etnohistory dapat disebut juga dengan mixed epistemologis (Strong, 2015). Mixed epistemologis yakni pendekatan yang mengandalkan beragam mode penjelasan dan validasi kajian sejarah budaya (Rogers, 1993). Proses ini dilakukan untuk menemukan hubungan keterkaitan antara budaya dan objek sejarah yang diteliti (Galloway, 2006). Pada tahapan terakhir, artikel ini menyajikan laporan hasil penelitian dari awal hingga akhir sehingga apa saja yang menjadi tujuan penelitian dapat terjawab. Dalam penulisan hasil penelitian ini, disajikan dengan cara mengisahkan fakta-fakta sejarah berdasarkan kronologisnya menjadi suatu eksplanasi sejarah yang berguna bagi pengembangan studi sejarah, budaya, dan pendidikan sejarah.

\section{Hasil dan Pembahasan}

Tenun merupakan proses pembuatan kain, dan pada prinsipnya kain tenun terjadi karena adanya persilangan antara dua benang yang terjalin saling tegak lurus satu sama lainnya (Akkapurlaura, 2015; Guslinda, 2017). Widati dan Poerwadarminta dalam Dariana (2020), mengartikan tenun sebagai hasil kerajinan berupa kain dari bahan yang dibuat benang (kapas, sutra dan sebagainya) dengan cara memasukkan bahan secara melintang pada lusi. Menurut (Affendi, 1989), kebudayaan menenun mulai muncul di Mesopotonia dan Mesir pada tahun 500 Sebelum Masehi. Keterampilan menenun tersebut kemudian menyebar ke Eropa dan Asia terutama Cina dan India. Kartiwa (1981), menambahkan bahwa tradisi menenun sutera dan songket dibawa oleh pedagang-pedagang Islam Arab dan India yang menguasai perdagangan di Asia Tenggara. Para pedagang ini membawa barang-barang dagangan tersebut dengan ajaran-ajaran agama Islam melalui Selat Malaka ke Pelabuhanpelabuhan Sumatera dan Pantai Utara Jawa. Terkait kemampuan menenun, di Indonesia sudah dikenal sejak beberapa abad silam. Hal ini disebabkan karena Indonesia telah melakukan hubungan perdagangan secara langsung telah antar negara-negara Asia dan Eropa (seperti India, China, Arab, Portugis dan Belanda) sehingga hubungan perdagangan tersebut telah merasuk ke ranah yang meningkatkan cipta dan kreasi seni kerajinan di beberapa wilayah Indonesia, khususnya seni kerajinan tenun (Viatra, Aji Windu; \& Triyanto, 2014). Pengetahuan ini merupakan kelanjutan dari pengetahuan membuat barang-barang kerajinan dengan teknik anyam yang terbuat dari serat dan berupa daun-daun, serat kayu yang digunakan sebagai pakaian dan wadah barang-barang. Perkembangan tenun ini mengarah pada kualitas bahan-bahan yang digunakan dan mulai mengenal motif serta warna yang sangat di prioritaskan pada produk tenun tersebut (Falashifa, 2013).

Dalam sejarah tenun di Indonesia menurut (Purwanti, R., \& Siregar, 2016) diketahui adanya berbagai macam tenunan yang diproduksi dengan menggunakan motif hias dari berbagai benang dan tersebar hampir di seluruh wilayah Indonesia. 
Keragaman budaya Indonesia tercermin dari penggunaan desain pakan tambahan yang membuat terciptanya tenunan yang berbeda-beda dalam bentuk motif, sehingga memunculkan identitas kelokalan daerah pembuatnya. Motif dan corak tenun yang dihasilkan di setiap daerah tidak sama dan mempunyai makna tersendiri, sehingga tenun pada suatu masyarakat memiliki motif khas yang berbeda dengan daerah lain, seperti kain Tenun Siak dari Riau, Indonesia.

Berkembangnya kain tenun tradisional khas Riau tidak lepas dari peranan tokoh-tokoh masyarakat (Lestari, S. \& Riyanti, 2017). Kain tenun Siak awalnya diperkenalkan oleh seorang pengrajin yang didatangkan dari Kerajaan Terengganu Malaysia pada masa Kerajaan Siak diperintah oleh Sultan Sayid Ali (Dasrol, 2013). Seorang wanita bernama Wan Siti Binti Wan Karim dibawa ke Siak Sri Indrapura, Salah satu tokoh wanita Melayu Riau yang juga sangat berperan dalam mengembangkan kerajinan kain tenun Siak di Riau adalah Tengku Maharatu. Tengku Maharatu adalah permaisuri Sultan Syarif Kasim II yang kedua, setelah permaisuri pertama, Tengku Agung meninggal dunia. Dia melanjutkan perjuangan kakaknya dalam meningkatkan kedudukan kaum perempuan di Siak dan sekitarnya, yaitu dengan mengajarkan cara bertenun yang kemudian dikenal dengan nama tenun Siak (Muzayyan, C., 2019). Tenunan Siak ini kemudian menjadi pakaian adat Melayu Riau (Koentjaraningrat, 2007). Bahkan tenunan Siak memiliki kesamaan di beberapa daerah seeprti tenunan Sambas di Kalimantan Barat. Hal ini dikarenakan daerah tersebut dulunya merupakan daerah taklukan Kerajaan Siak Sri Indrapura (Jamil, 2006).

Keterampilan menenun juga diwariskan melalui lembaga pendidikan yang terkenal pada masanya yaitu Sultanah Latifah School yang memiliki peran dalam diseminasi kerajinan tenun Siak yang didirikan oleh Tengku Agung (Wilaela, 2014). Ide Tengku Agung untuk mendirikan sekolah khusus perempuan diinspirasikan dari lawatannya ke Medan dan kenangannya terhadap kehidupan masa kecilnya di Tanjungpura, Langkat (Wilaela, 2015). Menurut Malik (2003), tahun 1764 pembuatan kain tenun menggunakan bahan dari ulat sutera alam. Benang sutera yang digunakan pada kain tenun Siak ini berasal dari Tionghoa (Cina) dipadu dengan benang emas dan perak dari India. Bahan material pembuatan kain tenun ini memang berasal dari Cina dan India. Karena ternyata sejak dahulu pedagang Cina dan India telah menjalin hubungan dagang dengan kerajaan Melayu di Indonesia (Lestari, S. \& Riyanti, 2017).

Kegiatan menenun sempat terhenti pada masa penjajahan Jepang. Hal ini disebabkan oleh putusnya distribusi bahan baku dari luar negeri. Masyarakat pada masa tersebut terpaksa menggunakan karung goni sebagai ganti pakaian kain. Sebelumnya, bahan baku berupa benang emas didatangkan dari Singapura oleh para pedagang melalui Pelabuhan Pelita Pantai di Sungai Siak. Kegiatan bertenun baru dilakukan kembali setelah Indonesia merdeka yaitu sejak tahun 1950 yang dipelopori oleh Hajjah Zaitun dari Bengkalis. Bahan baku tidak lagi menggunakan benang sutera, tetapi sudah diganti dengan benang dari kapas. Hal ini disebabkan oleh mahalnya harga-harga benang sutera, emas dan perak tersebut. Pada zaman dahulu, para pengrajin tenun melakukan sendiri proses pemintalan kapas ini hingga menjadi 
benang. Di wilayah Siak ada seorang pengrajut benang bernama Masajo yang kisah hidupnya tertuang dalam tulisan budayawan terkenal Yusmar Yusuf dengan judul "dari kapas menjadi benang, benang dirajut menjadi kain". Kisah masajo diceritakan bagaimana dengan gigihnya pada masa pendudukan Jepang terpaksa menyelesaikan pesanan tentara Jepang. Pada masa tersebut, Masajo diberi hadiah berupa $100 \mathrm{Kg}$ padi dan bahkan Masajo selama hidupnya dapat menunaikan ibadah haji dua kali (Sutrisno, 2012). Peran Masajo sangat berarti bagi kelangsungan tradisi menenun kain tradisional Melayu Siak. Proses pembuatan benang sendiri dimulai dari biji-biji kapas yang baru dipanen dikeluarkan dengan cara dijemur, setelah biji-bijinya dipisahkan kemudian kapas dipintal menjadi benang. Namun saat ini, para pengrajin tidak perlu memintal kapas lagi, karena benang untuk membuat tenunan telah banyak dijual di toko-toko.

Benang yang dijadikan bahan pokok pembuatan kain tenun Siak ini dapat dibagi dalam beberapa kategori, yaitu : benang lusi (lungsi), benang pakan, dan benang emas. Benang lusi juga biasa disebut benang kilo, karena dalam membuat dan menentukan jumlah helai kain dihitung berapa kilo benang yang dibutuhkan. Benang lusi warna dasarnya adalah putih, jika memerlukan warna yang lain maka kita dapat mencelupkannya sesuai warna yang diinginkan. Benang ini merupakan bahan pokok dalam pembuatan kain tenun. Sebelum digunakan, benang lusi harus melalui proses menerau agar benang tersebut dapat diurai sehingga tidak mudah kusut.

Benang pakan biasa disebut sebagai benang rajut atau benang kait. Bahan benang bisa dari benang kilo yang dirangkap dua atau dari benang jahit yang sudah paten. Benang pakan berfungsi sebagai benang perajut kekiri dan kekanan sehelai demi sehelai.Sedangkan benang emas, benang ini dapat dibagi menjadi beberapa macam : benang emas besar, benang emas kecil, dan benang bordir. Benang emas besar mempunyai fungsi sebagai hiasan kepala kain atau hiasan bunga pada kain tenunan. Fungsi benang emas ini sangat penting karena bila benang emas tidak dipakai, keindahan serta keunikan kain tenun tidak akan tampak. Benang emas kecil hanya dipakai untuk hiasan tambahan yang biasanya dimotifkan pada pinggir dan tengah kain. Sedangkan benang bordir hanya dipakai untuk hiasan pada selendang yang terbuat dari kain tenun (Sutrisno, 2012).

Proses pembuatan Kain Tenun Siak mengalami perubahan dari masa ke masa. Selain dari bahan baku yang mengalami perubahan, alat tenun yang digunakan juga mengalami perubahan. Perubahan hal terjadi karena bahan baku mulai terbatas sehingga mencari alternatif yang lain, sedangkan perubahan alat tenun untuk efisiensi produksi dan perkembangan teknologi. Sejak Kerajaan Siak berada dibawah kepemimpinan Sultan Ismail tahun 1764 alat tenun yang pertama kali digunakan adalah alat tenun tumpu. Alat tenun ini sudah disediakan untuk membuat kain kaum bangsawan. Pada tahun 1926 ketika Kerajaan Siak masih berada dibawah kepemimpinan Sultan Syarif Kasim II, beliau semakin mengembangkan keterampilan tenun kepada perempuan-perempuan Siak melalui sekolah Latifah School yang merupakan ide/gagasan permaisuri Sultan yaitu Tengku Agung (Hasnah, 2020). Di masa Sultan Syarif Kasim II pun alat tenun yang digunakan masih alat tenun tumpu. 
Alat tenun tumpu ini masih sangat sederhana, hal ini terlihat dari bentuk alatnya dan bagian-bagian dari alat tenun tumpu tersebut. Adapun bagian-bagian dari alat tenun tumpu, yaitu kayu empat persegi, kayu pelintang benang, karaf (alat pemisah benang atas dengan bawah), sisir benang (alat pemisah susunan benang lungsi), kain penahan badan, papan landasan, dan kayu pelontar benang. Kain yang dihasilkan dari alat tenun tumpu ini kurang rapi, hal ini dikarenakan alat tenun tumpu hanya mengandalkan gerak tangan dan kaki. Lebar kain yang dihasilkan juga tidak selebar kain tenun saat ini. Jika menggunakan alat tenun tumpu, untuk mendapatkan kain yang lebar maka harus menyambung beberapa tenunan. Namun, alat ini telah menjadi pelopor yang nyata untuk perkembangan budaya tenun di Siak Sri Indrapura.

Karena adanya hubungan baik antara kerajaan Siak dengan kerajaan-kerajaan asing, sehingga melalui hubungan itu terjadi pertukaran budaya yang cukup pesat. Pertukaran budaya itu meliputi perkembangan alat-alat budaya seperti alat tenunan. Akibat dari pertukaran dan hubungan budaya yang baik itu perkembangan alat-alat tenun semakin maju dan alat-alat tenun yang dipakai sudah mulai beranjak sempurna. Alat tenun tumpu digunakan hingga tahun 1980an, dan sejak tahun 1980an penggunaan alat tenun tumpu sudah mulai digantikan dengan alat tenun baru, yaitu Kik.

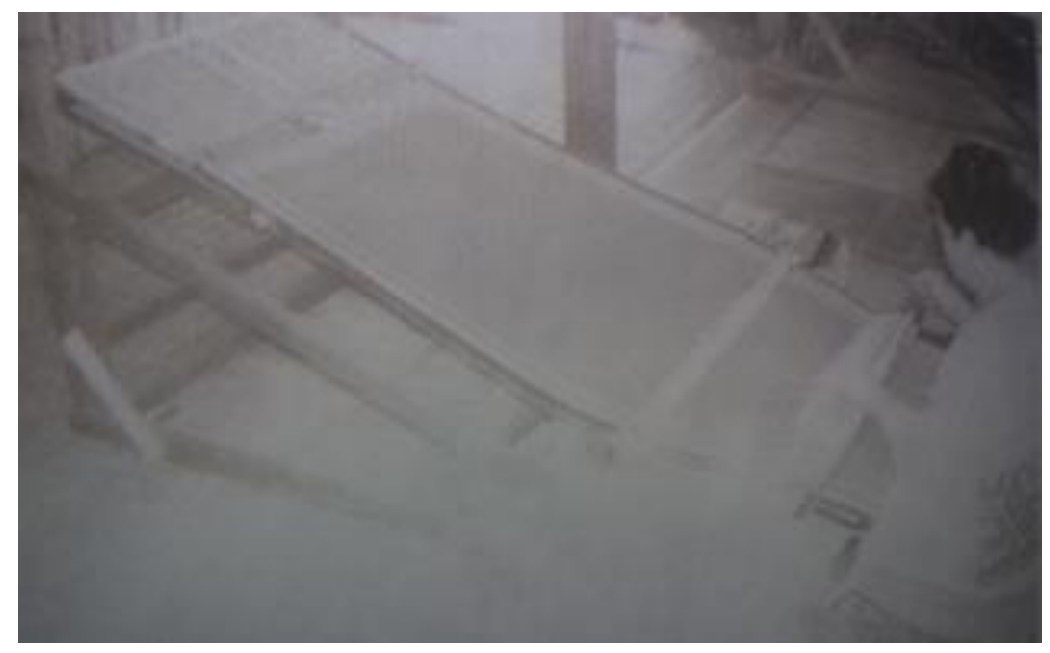

Gambar 1. Alat Tenun Tumpu Sumber : Sutrisno, 2012.

Pada tahun 1984 tenun Tumpu yang digunakan oleh Encik Siti dan beberapa kaum perempuan Kerajaan Siak waktu itu berangsur-angsur ditinggalkan. Karena peradaban manusia yang selalu meningkat serta tingkat kemajuan kebudayaan yang dialami cukup berkembang. Pada akhirnya tenun tumpu diganti dengan alat tenun yang lebih disempurnakan, ada perubahan pada tempat duduk bagi penenun yang menempati dudukan sedemikian rupa, sehingga penenun dapat duduk tersendiri yang disebut kik. Alat tenun kik ini sudah sedikit maju dibanding dengan alat tenun tumpu. Dalam 
perkembangannya alat tenun kik ini adalah pengembangan dari alat tenun tumpu. Manusia terus mencari dan mengembangkan akal dan pikiran untuk dapat menyempurnakan alat tenun. Menurut sejarah kata kik atau kek yang berasal dari bahasa siam berarti menyungkit, sama dengan songkok dalam bahasa Cina yang berarti sama (Jamil, 2020). Alat tenun ini bertahan cukup lama, sehingga masyarakat dengan mudah membuatnya sendiri.

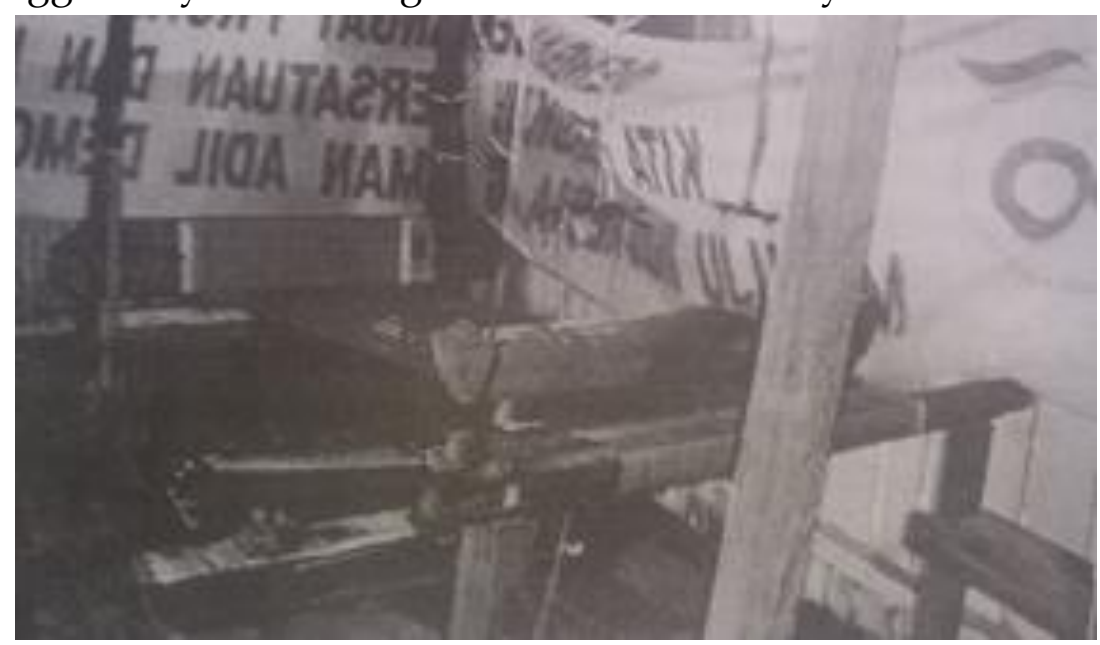

Gambar 2. Alat Tenun Kik

Sumber : Sutrisno, 2012.

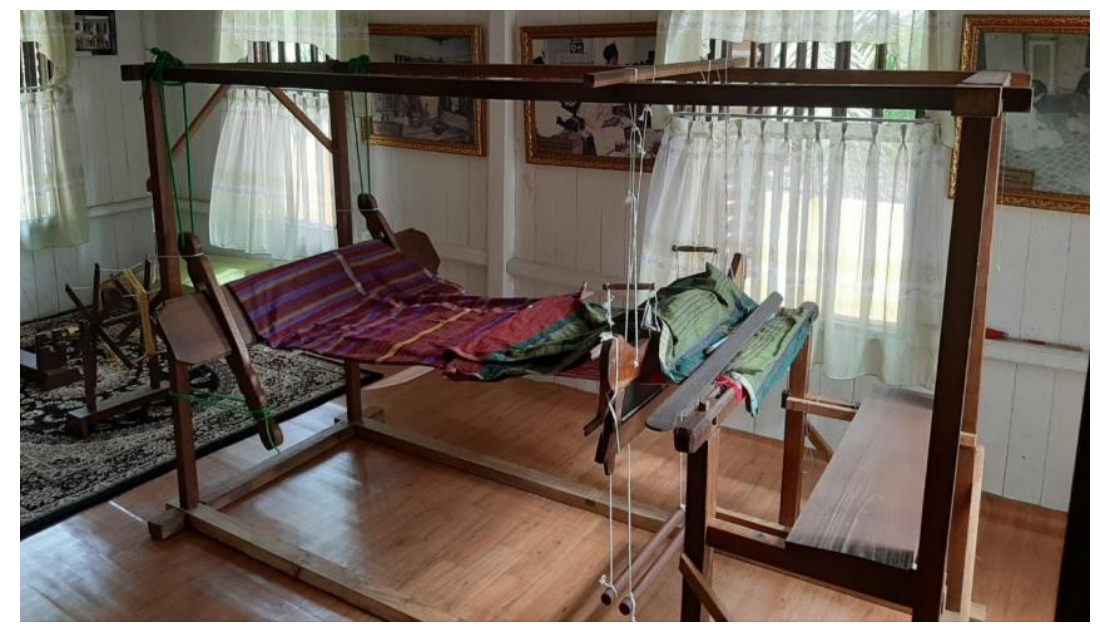

Gambar 3. Peninggalan Alat Tenun Kik

Sumber : Dokumen Pribadi, 2020.

Perbedaan yang nampak dari tenun tumpu dengan alat tenun kik adalah terletak pada posisi penenun. Jika pada alat tenun tumpu penenun duduk pada landasan papan, berbeda halnya dengan alat tenun kik, penenun duduk pada sebuah tempat duduk yang lebih tinggi, sehingga penenun dapat leluasa dalam mengerjakan hasil tenunan. Alat tenunan ini mempunyai dudukan yang dikatakan rumah tenun, karena bentuknya persegi menyerupai kerangka persegi panjang. Alat tenun kik ini mempunyai bagian-bagian antara lain papan gulung, belebas (alat untuk menyusun 
dan mengatur benang yang akan dimasukkan ke karaf), gerop (tempat sisir untuk merapatkan benang), keraf (alat pertama yang dilalui oleh benang), sisir (untuk menyusun benang agar bisa menjadi kain), torak, peleting, kik, dan balero (Jamil, 2020). Pada akhirnya alat tenun kik, jarang digunakan lagi karena alat ini lambat dalam pembuatan tenun songket (Guslinda, 2017).

Alat tenun Kik mengalami perubahan yang lebih maju yaitu alat tenun bukan mesin. Dinamakan alat tenun bukan mesin karena cara kerja alat ini hampir menyerupai kerja mesin tetapi menggunakan tenaga manusia.

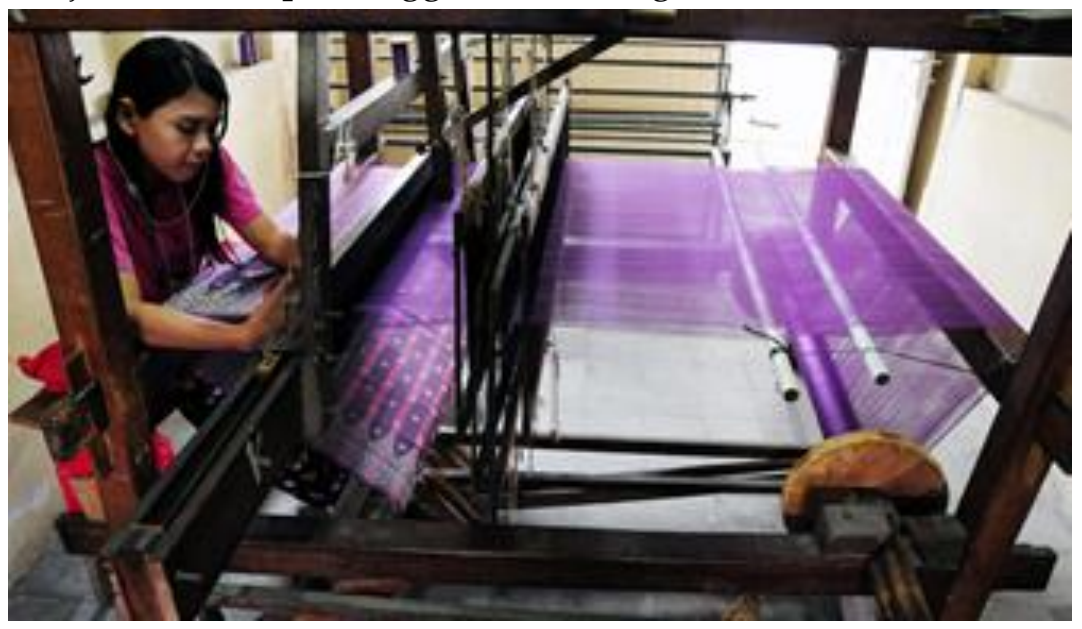

Gambar 4. Alat Tenun Bukan Mesin

Sumber : Sutrisno, 2012.

Sejak tahun 1990-an penggunaan alat tenun Kik telah digantikan dengan alat tenun bukan mesin (ATBM). Alat tenun bukan mesin (ATBM) mulai digunakan sejak tahun 1990-an hingga sekarang. ATBM ini lebih komplit bagian-bagiannya, juga dudukan rumah yang kokoh dan kuat karena memakai bahan dasar kayu yang lebih besar serta kualitas kayu yang lebih bagus. Hasil produksi kain yang dihasilkan juga lebih cepat karena daya kerja alat juga maksimal. Alat ini juga dapat menghasilkan kain lebih banyak, harga per unit mesin ini mencapai jutaan rupiah tergantung dengan jenis kayu yang dibuat mesin. Alat ini merupakan pengembangan dari alat tenun kik yang sudah ada untuk menghasilkan karya tenun Siak. Tenun Siak yang merupakan sebagai warisan budaya yang merupakan bagaian integral dari konfigurasi kebudayaan tentu dalam keberadaannya perlu dilestarikan dan diwariskan pada generasi mendatang (Guslinda., Kurnia, R., 2020).

\section{Simpulan}

Proses pembuatan tenun Melayu Siak telah mengalami perubahan dari waktu ke waktu dari segi alat dan bahan. Bahan yang digunakan pertama kali adalah benang sutera, emas, dan perak. Bahan baku tersebut kemudian mengalami perubahan menjadi bahan baku dari benang kapas. Hal ini disebabkan oleh bahan baku sebelumnya memiliki harga yang mahal dan susah didapatkan pada masa penjajahan. Bahkan pada masa penjajahan Jepang di Riau, Indonesia aktifitas menenun terhenti 
Bunari, Asyrul Fikri, Piki Setri Pernantah, Yanuar Al-Fiqri

Perkembangan Pembuatan Tenun Melayu Siak : Suatu Tinjauan Historis

karena ketiadaan bahan baku. Selain bahan baku yang mengalami perubahan, penggunaan alat juga mengalami perkembangan hingga masa kemerdekaan saat ini. Perkembangan alat tenun disebabkan oleh kemajuan teknologi dan kemampuan manusia dalam membuat kain tenun. Alat tenun yang digunakan dimulai dari alat tenun tumpu, kemudian berganti dengan alat tenun kik dan terakhir yaitu alat tenun bukan mesin atau ATBM. Selain itu, alat tenun yang dikembangkan bertujuan unuk menghasilkan tenun yang berkualitas dan waktu pengerjaan yang singkat.

\section{Daftar Rujukan}

Abdulsyani. (2007). Sosiologi: Skematika, Teori, dan Terapan. Bumi Aksara. Affendi, Y. (1989). Seni Tenun Silungkang dan Sekitarnya. Direktorat Jendral Kebudayaan Departemen pendidikan dan Kebudayaan Padang.

Akkapurlaura. (2015). Pengembangan Motif Rantai, Tampuk Manggis, Pucuk Rebung, Siku Awan, dan Lebah Bergayut Pada Kain Songket Melayu Riau. Prosiding Seminar Nasional Cendekiawan.

Dali, Z. (2016). Hubungan Antara Manusia, Masyarakat, dan Budaya Dalam Perspektif Islam. NUANSA, XI(1), 47-56.

Dariana, D. (2020). Penetapan Harga Pokok Produksi Dengan Metode Full Costing Sebagai Dasar Penentuan Harga Jual Kain Tenun Songket Melayu. JAS (Jurnal Akuntansi Syariah), 4(2), 258-270.

Dasrol. (2013). Analisis Terhadap Hambatan Pelaksanaan Perlindungan Hukum Tenun Siak di Kabupaten Siak Berdasarkan Undang-Undang Nomor 19 Tahun 2002 Tentang Hak Cipta. Jurnal Hukum Dan Pembangunan, 43(1), 1-26.

Falashifa, D. I. (2013). Kerajinan Tenun Ikat Tradisional Home Industry Dewi Shinta di Desa Troso Pecangan Kabupaten Jepara (Kajian Motif, Warna, Dan Makna Simbolik). Universitas Negeri Yogyakarta.

Galloway, P. (2006). Practicing Ethnohistory: Mining Archives, Hearing Testimony, Constructing Narratives. University of Nebraska Press.

Guslinda., Kurnia, R., \& M. (2020). The Development Of Social Studies Teaching Materials Based On Malay Siak Songket Weaving For Fourth Grade Elementary School Students. Jurnal PAJAR (Pendidikan Dan Pengajaran), 4(5), 1057-1069.

Guslinda. (2017). Kerajinan Tenun Songket Melayu Riau Untuk Pelestarian Kearifan Lokal. JURNAL PIGUR, 2(1), 124-130.

Guslinda \& Kurniaman, O. (2016). Perubahan Bentuk, Fungsi, dan Makna Tenun Songket Siak Pada Masyarakat Melayu Riau. Primary. Jurnal Pendidikan Guru Sekolah Dasar, 5(1), 29-42.

Hasnah, E. (2020). Wawancara Tokoh Perempuan Riau yang melestarikan Tenun Siak. Pekanbaru, 30 Juni 2009. Ia belajar menenun dari neneknya, Hajah Aminah, yang belajar dari Tengku Agung.

Ibrahim, B., Fikri, A., \& Pernantah, P. (2019). Integration of Siak Songket Weaving Values Through Value Clarification Technique to Reinforcement of the Meaningful History Learning. Proceedings of the International 
Conference On Social Studies, Globalisation And Technology (ICSSGT 2019). Advanc.

Jamil, O. K. N. (2006). Kain Tenunan Tradisional Siak. Seminar Kerajinan Tenunan Siak.

Jamil, O. K. N. (2020). Wawancara. Pekanbaru. 30 Oktober 2009. Ia bercerita berdasarkan kisah dari kedua orang tuanya, ibunya adalah anak angkat Tengku Maharatu, sementara ayahnya adalah sekretaris pribadi Sultan Syarif Kasim II.

Joko, T. P. (2009). Ilmu Budaya Dasar. Rineka Cipta.

Kartiwa, S. (1981). Kain Songket Indonesia. Djambatan.

Kistanto, N. (2017). Tentang Konsep Kebudayaan. ,. Sabda: Jurnal Kajian Kebudayaan, 10(2), 1-11.

Koentjaraningrat. (2007). Masyarakat Melayu dan budaya Melayu dalam perubahan. Balai Kajian dan Pengembangan Budaya Melayu bekerjasama dengan Adicita Karya ....

Koentjaraningrat. (2019). Traditional Embroidery as a Method of Decoration in Najd Desert Tribes DOI: 10.33552/JTSFT.2019.04.000587. J Textile Sci E Fashion Tech, 4(3), 1-8.

Lestari, S. \& Riyanti, M. . (2017). Kajian Motif Tenun Songket Melayu Siak Tradisional Khas Riau. Jurnal Dimensi Dkv Seni Rupa Dan Desain, 2(1), 3348.

Malik, A. et al. (2003). Corak dan Ragi Tenun Melayu Riau. Balai Kajian dan Pengembangan Budaya Melayu, Yogyakarta bekerja sama dengan Penerbit Adicita Karya Nusa.

Maulia, R. (2015). Wisata Budaya dalam Tradisi Tenun di Kecamatan Mempura Kabupaten Siak. JOM, 2(2), 1-11.

Muzayyan, C., \& E. (2019). Studi Tentang Kain Tenun Siak di Usaha Ncik Hasnah Pekanbaru Riau. Journal of Public Policy Management and Administration, 1(1), 79-104.

Pitoyo, A.J., \& Triwahyudi, H. (2017). Dinamika Perkembangan Etnis di Indonesia Dalam Konteks Persatuan Negara. Populasi, 25(1), 64-81.

Prayogi, A. (2016). Dinamika Identitas Budaya Melayu Dalam Tinjauan ArkeoAntropologis. Tamaddun: Jurnal Kebudayaan Dan Sastra Islam, 16(1), 1-20.

Purwanti, R., \& Siregar, S. M. (2016). Sejarah Songket Berdasarkan Data Arkeologi. Siddhayatra, 21(2), 97-106.

Rogers, J. . (1993). Ethnohistory and Archaeology: Approaches to postcontact change in the Americas. Plenum Press.

Roza, E. (2012). Tinjauan Sejarah Terhadap Naskah dan Teks Kitab Pengetahuan Bahasa, Kamus Logat Melayu Johor Pahang Riau Lingga Karya Raja Ali Haji. Jurnal Sosial Budaya, 9(2), 172-194.

Sirajuddin, M. (2014). Wacana Hukum Islam Lintas Budaya. IPB Press.

Strong, P. . (2015). Ethnohistory, dalam J. D. Wright (ed.), International Encyclopedia of the Social and Behavioral Sciences, 8, 2nd ed. Elsevier.

Suadnyana, I. B. P. E. (2020). Kain Tenun Cagcag pada Upacara Manusa Yadnya di Kelurahan Sangkaragung Kabupaten Jembrana. Jñ̄nasiddhânta: Jurnal Prodi Teologi Hindu STAHN, 2(1), 51-60. 
Bunari, Asyrul Fikri, Piki Setri Pernantah, Yanuar Al-Fiqri

Perkembangan Pembuatan Tenun Melayu Siak : Suatu Tinjauan Historis

Sutrisno, P. (2012). Seluk Beluk Tenunan Siak. UR Press.

Viatra, Aji Windu; \& Triyanto, S. (2014). Seni Kerajinan Songket Kampoeng Tenun di Indralaya Palembang. Jurnal Ekspresi Seni, 16(2), 168-183.

Wahyudi, J., \& dan Maulida, I. (2019). Pengenalan Pola Citra Kain Tradisional Menggunakan GLCM dan KNN. JTIULM, 4(2), 43-48.

Wilaela. (2014). Sultanah Latifah School Di Kerajaan Siak (1927-1945). Sosial Budaya: Media Komunikasi Ilmu-Ilmu Sosial Dan Budaya, 11(1), 124-143.

Wilaela. (2015). Pendidikan Jalan Tengah Di Kerajaan Siak (1915-1945). Sosial Budaya: Media Komunikasi Ilmu-Ilmu Sosial Dan Budaya, 12(1), 117-126. 